\title{
Recent Advances in Underlying Pathologies Provide Insight into Interleukin-8 Expression-Mediated Inflammation and Angiogenesis
}

\author{
Basit Saleem Qazi, ${ }^{1}$ Kai Tang, ${ }^{1}$ and Asma Qazi ${ }^{2}$ \\ ${ }^{1}$ Department of Orthopedic Surgery Spine Unit, First Affiliated Hospital of Dalian Medical University, 222 Zhongshan Road, \\ Dalian, Liaoning 116011, China \\ ${ }^{2}$ Department of Pathology and Pathophysiology, Dalian Medical University, 9 West Section Lvshun South Road, Lvshun District, \\ Dalian, Liaoning 116044, China
}

Correspondence should be addressed to Kai Tang, dltangkai@yahoo.com

Received 23 April 2011; Revised 15 August 2011; Accepted 6 September 2011

Academic Editor: B. L. Slomiany

Copyright ( 2011 Basit Saleem Qazi et al. This is an open access article distributed under the Creative Commons Attribution License, which permits unrestricted use, distribution, and reproduction in any medium, provided the original work is properly cited.

Interleukin-8 has long been recognized to have anti-inflammatory activity, which has been established in various models of infection, inflammation, and cancer. Several cell types express the receptor for the cytokine IL-8 and upon its recognition produce molecules that are active both locally and systemically. Many different types of cells, in particular monocytes, neutrophils, epithelial, fibroblast, endothelial, mesothelial, and tumor cells, secrete IL-8. Increased expression of IL-8 and/or its receptors has been characterized in many chronic inflammatory conditions, including psoriasis, ARDS, COPD, and RA as well as many cancers, and its upregulation often correlates with disease activity. IL-8 constitutes the CXC class of chemokines, a potent chemoattractant and activator of neutrophils and other immune cells. It is a proangiogenic cytokine that is overexpressed in many human cancers. Therefore, inhibiting the effects of IL-8 signaling may be a significant therapeutic intervention.

\section{Introduction}

IL-8 is secreted by multiple cell types, including monocytes, neutrophils, epithelial, fibroblast, endothelial, mesothelial, and tumor cells. It is released from several cell types in response to an inflammatory stimulus [1]. IL-8 plays an important role in inflammation and wound healing [2] and has a capacity to recruit $\mathrm{T}$ cells as well as nonspecific inflammatory cells into sites of inflammation by activating neutrophils [3]. It also stimulates $\alpha$-smooth muscle actin production in human fibroblasts [4]. Furthermore, IL-8 is chemotactic for fibroblasts, accelerates their migration, and stimulates deposition of tenascin, fibronectin, and collagen I during wound healing in vivo [4]. This paper summarizes current knowledge on the central role of IL-8 in different pathologies. The experimental results and questions posted in research work on IL- 8 are covered here, and the potential roles of IL-8 as part of a complex cytokine network in wound healing, angiogenesis, and several cancers are discussed here.

\section{Expression of IL-8 in Immune System}

In many cell types, the synthesis of IL-8 is strongly stimulated by IL- 1 and TNF- $\alpha$. In human skin fibroblasts, the expression of IL-8 is enhanced by leukoregulin. The synthesis of IL8 is induced also by phytohemagglutinins, concanavalin A, double-stranded RNA, phorbol esters, sodium urate crystals, viruses, and bacterial lipopolysaccharides. The expression of IL-8 from resting and stimulated human blood monocytes is upregulated by IL-7 [5].

In chondrocytes, the synthesis of IL-8 is stimulated by IL1- $\beta$, TNF- $\alpha$, and bacterial lipopolysaccharides. In human astrocytes, the synthesis and secretion of IL- 8 is induced by IL- 1 and TNF- $\alpha$. Glucocorticoids, IL- 4 , TGF- $\beta$, inhibitors 
of $5^{\prime}$ lipoxygenase, and $1.25(\mathrm{OH}) 2$ vitamin D3 inhibit the synthesis of IL-8. IL- 8 is constitutively and commonly produced by various carcinoma cell lines, and this synthesis may be related to the elevation of serum IL-8 in patients with hepatocellular carcinoma. In epithelial, endothelial, and fibroblastic cells, secretion of IL-8 is induced by IL-17 [6].

\section{Protein Characteristics}

IL-8 is an $8.4 \mathrm{kDa}$ nonglycosylated protein produced by processing of a precursor protein of 99 amino acids belonging to the CXC subfamily of chemokines which is characterised by two essential cysteine residues, separated by a third intervening amino acid $[7,8]$. There are two major forms of IL-8, that are the 72-amino acid monocyte-derived form, predominant in cultures of monocytes and macrophages, and the endothelial form which has five extra N-terminal amino acids, predominating in cultures of tissue cells such as endothelial cells and fibroblasts $[9,10]$.

Longer forms of IL-8 (79 and 77 amino acids) and shorter forms (69 amino acids) have been isolated also from conditioned medium of lymphocytes stimulated with bacterial lipopolysaccharides, fibroblasts stimulated by IL1 or TNF, and polyI: C-stimulated endothelial cells. The predominant form of IL-8 produced by endothelial cells (and also by anchorage-dependent cells and human glioblastoma cells) is the 77-amino acid variant. IL-8 (6-77) has a 510-fold higher activity on neutrophil activation, IL-8 (577) has increased activity on neutrophil activation, and IL-8 (7-77) has a higher affinity to receptors CXCR1 and CXCR2 as compared to IL-8 (1-77), respectively [11].

\section{IL-8 Structure}

The human IL-8 gene (SCYB8) has a length of $5.1 \mathrm{~kb}$ and maps to human chromosome 4q12-q21. The mRNA consists of a 101-base $5^{\prime}$ untranslated region, an open reading frame of 297 bases and a long $3^{\prime}$ untranslated region of $1.2 \mathrm{~kb}$. The $5^{\prime}$ flanking region of the IL-8 gene contains potential binding sites for several nuclear factors including activation factor1 , activation factor-2, IFN regulatory factor-1, hepatocyte nuclear factor-1, a glucocorticoid-responsive element, and a heat shock element $[12,13]$.

\section{IL-8 and Receptors}

IL-8 receptors are a member of a G-protein-coupled receptor protein family. There are at least two different IL-8 receptor types. The type 1 receptor specifically binds IL-8 $(\mathrm{Kd}=$ $0.8-4 \mathrm{nM}$ ). The type 2 receptor (Kd for IL- $8=0.3-2 \mathrm{nM}$ ) also binds the IL-8-related factors like MGSA (melanoma growth stimulatory activity), GRO, MIP-2 (macrophage inflammatory protein), and NAP-2 (neutrophil-activating protein-2). Both receptor genes map to human chromosome 2q35 [13-15].

\section{Biological Functions and Expression of IL-8}

The activities of IL-8 are not species specific. Human IL8 is also active in animal cells. The biological activities of IL-8 resemble those of a related protein, NAP-2 (neutrophilactivating protein-2). It differs from all other cytokines in its ability to specifically activate neutrophil granulocytes where it causes a transient increase in cytosolic calcium levels and the release of enzymes from granules. IL- 8 also enhances the metabolism of ROS (reactive oxygen species) and increases chemotaxis and the enhanced expression of adhesion molecules [16].

IL-8 alone does not release histamines. It actually inhibits histamine release from human basophils induced by histamine-releasing factors, CTAP-3 (connective tissue activating protein-3), and IL-3 [17]. IL-8 is involved also in pain meditation [18]. The intravenous administration of IL8 in baboons causes a severe granulocytopenia followed by granulocytosis which persists as long as sufficient IL-8 levels are maintained [19].

IL-8 is chemotactic for all known types of migratory immune cells. IL- 8 inhibits the adhesion of leukocytes to activated endothelial cells and therefore possesses antiinflammatory activities. The 72 -amino acid form of IL- 8 is approximately tenfold more potent in inhibiting adhesion of neutrophils than the 77-amino acid variant [20].

IL-8 is a mitogen for epidermal cells, and in vivo it strongly binds to erythrocytes. This absorption may be of physiological importance in the regulation of inflammatory reactions since IL- 8 bound to erythrocytes no longer activates neutrophils. Macrophage-derived IL-8 supports angiogenesis and plays role in disorders such as rheumatoid arthritis, tumor growth, and wound healing that critically depend on angiogenesis [21].

Simonet et al. (1994) have studied transgenic mice overexpressing IL-8. Elevated serum IL-8 levels were found to correlate with increases in circulating neutrophils and decreases in L-selectin expression on the surface of blood neutrophils. The accumulation of neutrophils was observed in the microcirculation of the lung, liver, and spleen. Neutrophil extravasation, plasma exudation, or tissue damage was absent [22].

IL-8 has been implicated in a number of inflammatory diseases, such as CF [23], ARDS (adult respiratory distress syndrome) [24], COPD (chronic obstructive pulmonary disease), and asthma [25]. The airway epithelium is one of several sources of IL- 8 in the airway, and it serves as a barrier against invading microorganisms. Airway epithelial release of IL-8 contributes to host defense by promoting neutrophil chemotaxis and airway inflammation [26].

\section{Clinical Significance}

Inflammation is the single greatest cause of pain. The first inflammatory mediators recognized to have potent hyperalgesic properties was bradykinin [27], since then a host of inflammatory medicators have been identified which can produce hyperalgesia, including prostaglandins, 
leukotrienes, serotonin, adenosine, histamine, IL-1, IL-8, and NGF (nerve growth factor).

Cytokines are produced by leukocytes in response to exposure to bacterial toxins or to inflammatory medicators [28]. IL-8 has also been found to produce a sympatheticdependent hyperalgesia which does not appear to be medicated by prostaglandin $[18,29]$.

IL-8 was shown to be angiogenic factor in 1992 [21, 30]. Kitadai et al. Found high levels of IL-8 in six of eight carcinoma cells and lines and 32 of 39 gastric carcinoma specimens as compared to normal mucosal control. The levels of IL- 8 correlated strongly with the specimen vascularity [31]. IL-8 was shown to be major inducer of neovascularisation of squamous cell carcinoma by lingen et al. [32]. IL-8 also plays a significant role in other cancer by mediating angiogenesis and tumorigenesis. IL- 8 is produced by a wide panel of human cancer cells including colon [10], melanoma [33], prostate [34], ovary $[35,36]$, or breast [3740].

\subsection{IL-8 and Inflammatory Diseases}

7.1.1. Proinflammatory Effects of IL-8. IL-8 is an oxidative stress-responsive proinflammatory chemokine, released from epithelial cells following particle-induced oxidative stress leading to neutrophil influx and inflammation $[41,42]$. IL- 8 is a potent chemoattractant and activator of neutrophils, the transcription of which is NF- $\kappa \mathrm{B}$ dependent [43].

Proinflammatory stimuli are considered to be a major regulator of IL-8 levels in response to injury. IL-8 is involved in many of the wound healing processes. It not only serves as a chemotactic factor for leukocytes and fibroblasts but also stimulates fibroblast differentiation into myofibroblasts and promotes angiogenesis $[44,45]$.

IL-8 is a proinflammatory cytokine that is upregulated by different cellular stress stimuli [46]. Human cells are characterized by their marked capacity for varying the expression levels of IL-8, allowing modulating the concentration of this cytokine to control the degree of neutrophil infiltration in the injured tissue [46]. The expression of IL- 8 is regulated at both transcriptional and posttranscriptional levels [47], and the main MAPK pathways (p38, MEK1/2, and JNK) play a significant role in the release of IL- 8 during the inflammatory process [46].

7.1.2. Enhancement of Corneal Wound Healing. The induction of IL- 8 facilitates an early innate immune response to infection in the corneal stroma and represents an elementary defense mechanism in corneal wound healing [48]. It enhances healing by rapidly chemoattracting leukocytes and fibroblasts into the wound site, stimulating the latter to differentiate into myofibroblasts. In turn, myofibroblasts are critical for wound contraction and closure and for the production of extracellular matrix molecules, which leads to development of granulation tissue [44].

The role of PDGF in corneal wound healing [49] and IL8-mediated neutrophil chemotaxis [50] has been previously documented. It enhances healing by rapidly chemoattracting leukocytes and fibroblasts into the wound site [2], where PDGF increases IL-8 chemokine secretion twofold in human corneal fibroblasts, indicating that IL-8 is involved in PDGFmediated corneal wound healing. Both human corneal keratocytes and epithelial cells have been shown to synthesize and release IL-8 following cytokine stimulation and/or infection [51].

7.1.3. Proliferation in Arthritis. IL- 8 may be of clinical relevance in psoriasis and rheumatoid arthritis. Elevated concentrations are observed in psoriatic scales, and this may explain the high proliferation rate observed in these cells. IL8 may be also a marker of different inflammatory processes [52].

IL-8 (and also IL-1 and IL-6) probably plays a role in the pathogenesis of chronic polyarthritis since excessive amounts of this factor are found in synovial fluids [53]. The activation of neutrophils may enhance the migration of cells into the capillaries of the joints. These cells are thought to pass through the capillaries and enter the surrounding tissues thus causing a constant stream of inflammatory cells through the joints [54].

7.1.4. Role in Myelodysplastic Syndrome. Human recombinant IL-8 has shown that the lesion responsible for defective functions of neutrophils in patients with myelodysplastic syndrome can be restored without stimulating myeloid progenitor cells. IL- 8 may be able, therefore, to reduce the risks of lethal infections in these patients without the potential risk of stimulating leukemic clones [55].

7.1.5. Gastric Mucosal Injury and Cancer Progress. In the human gastric mucosa, elevated levels of ROS are associated with Helicobacter pylori infection [56], and it leads to oxidative DNA damage in the gastric mucosa thereby contributing to mucosal injury and promoting carcinogenesis $[57,58]$. $\mathrm{H}$. pylori infection is also associated with increased gastric mucosal cytokine expression including IL-8 $[59,60]$ and TNF- $\alpha[61,62]$.

TNF- $\alpha$ is an endogenous mediator of proinflammatory cytokine stimulation and can induce ROS [63] and stimulate the induction of various genes involved in inflammation [64] including IL-8. IL-8 is an important mediator of H. pyloriassociated neutrophil infiltration and gastric inflammation [57]. ROS modulates IL-8 secretion in gastric epithelial cells, suggesting that IL- 8 gene expression in the gastric mucosa is redox sensitive [65].

Although a regulatory role of TNF- $\alpha$ in epithelial cell repair has been described [66], it is well established that TNF$\alpha$ stimulates IL- 8 and contributes to epithelial cell injury and apoptosis [63].

7.1.6. Increased BAL Fluid in ALI and COPD. In human ALI (acute lung injury), neutrophil infiltration is an early and important pathophysiological event, and IL-8 appears to have an important role in mediating this process $[67,68]$. Clinical research demonstrated increased IL-8 levels in serum 
and BAL (bronchoalveolar lavage) fluid of patients with ALI $[69,70]$. Increased BAL fluid levels of IL-8 predicted the development of ALI in at-risk patient populations and are associated with increased mortality in patients with ALI [71]. In animal models of ALI, administration of IL-8 antibody conferred protection [72]. IL-8 is also produced by respiratory epithelium [26].

Studies involving alveolar macrophages, U937 cells, isolated peripheral blood monocytes, and human whole blood demonstrated that hyperoxia modulates IL-8 gene expression [73]. Oxidant stress other than hyperoxia was previously described to induce IL-8 expression in respiratory epithelial cells. DeForge et al. [74] and Lakshminarayanan et al. [75] hyperoxia alone had a minimal effect on IL-8 gene expression. However, combination of hyperoxia and TNF-a synergistically increased IL-8 gene expression.

COPD (chronic obstructive pulmonary disease) cigarette smoke can also induce airway inflammation. It has been shown to activate proinflammatory transcription factors NF$\kappa \mathrm{B}$ and activator protein (AP)-1 [76] as well as to upregulate the expression of TNF- $\alpha$ and IL-8, proinflammatory mediators associated with COPD [77].

7.1.7. Prevention of Lung Epithelial Cells Injury. TNF- $\alpha$ levels are markedly elevated in BAL fluid from patients with ARDS [78], and TNF- $\alpha$ levels are associated with increased IL- 8 levels. TNF- $\alpha$ is a major inducer of IL- 8 expression in lung epithelial cells [26]. Neutralizing IL-8 antibodies prevented lung injury in animal models of lung disease, indicating IL-8 is an important mediator of lung injury $[79,80]$. IL-8 gene expression is induced by a wide variety of agents including cytokines, growth factors, bacterial and viral products, oxidants, and others [81]. Induction of IL8 gene expression is subject to both transcriptional and posttranscriptional regulation in a cell/tissue-and stimulusspecific manner $[46,81]$.

In lung epithelial cells, TNF- $\alpha$ activates IL- 8 promoter activity via recruitment of NF- $\kappa \mathrm{B}$ to a TNF- $\alpha$ response element consistent with a role for transcriptional mechanisms in the induction of IL-8 gene expression in lung epithelial cells [82].

7.1.8. Signalling in Cystic Fibrosis. IL-8 drives the inflammatory response in cystic fibrosis (CF) which is an autosomal recessive disorder caused by mutations in the gene encoding the cystic fibrosis transmembrane conductance regulator (CFTR) [83].

BAL fluid in patients with CF contains increased levels of proinflammatory cytokines and neutrophils. IL-8 levels attribute to activate NF- $\kappa \mathrm{B}[84]$. Prostaglandin E2 (PGE-2) is a potent mediator of inflammation produced by cyclooxgenation of arachidonic acid, and its hypersecretion results in elevated IL-8 secretion through unidentified signaling pathway [85].

In human $\mathrm{T}$ lymphocytes, PGE-2 induces C/EBP homologous protein (CHOP) transcription factor that binds to the IL- 8 promoter [85]. CHOP is a growth arrest and DNA damage-inducible gene 153 (GADD153) protein. PGE-2 mediates the IL-8 inflammatory response in CF cells through the CHOP transcription factor. The inflammatory response in CF contributes to neutrophil-driven lung destruction [ 86 , 87]. Several cytokines, such as IL- $1 \mathrm{~b}, \mathrm{TNF}-\alpha, \mathrm{IFN}-\delta$, and bacterial products, induce IL- 8 release from airway epithelial cells [88], thus exacerbating the baseline inflammatory milieu in CF.

Much of the PGE-2 in airways is likely to be derived from the epithelium [89], and the stimulation of chloride secretion in airway epithelial cells by proinflammatory mediators such as bradykinin (BK) occurs through the induced release of PGE-2 (26). Moreover, BK induces IL-8 secretion in non-CF and CF human airway epithelia [90].

The physiologic as well as pathologic concentrations up to $100 \mathrm{mM}$ PGE-2 upregulate endogenous IL-8 expression in human intestinal epithelial cells [91] and enhance IL-8 production in human synovial fibroblasts stimulated with IL-1b [92].

7.1.9. Increased Expression in Asthma. IL-8 plays an important role in inflammatory lung diseases like bronchial asthma or severe infections caused by respiratory syncytial virus (RSV), and during infancy it might lead to the development of recurrent wheezing and/or bronchial asthma [93]. Increased concentrations of IL- 8 are found in the BAL fluid and sputum of asthmatic patients [13]. In addition, repeated administration of IL- 8 into the airways induces bronchial hyperreactivity in guinea pigs [94]. Genetic association of IL8 has been described with asthma [95] and RSV bronchiolitis [96].

IL-8 binds with high affinity to two different receptors: IL- 8 receptor $\alpha$ (IL-8RA, CXCR1) and $\beta$ (IL-8RB, CXCR2). These closely related proteins are members of the super family of receptors, which couple to guanine nucleotide-binding proteins. IL-8RA is localized on chromosome 2q35 [13], where linkage to total serum IgE levels in asthmatics has been described [94]. Association of IL-8RA polymorphisms has recently been described with asthma and chronic obstructive pulmonary disease [95]. However, IL-8RA polymorphisms do not play a major role, neither in the development of severe RSV infections nor in asthma.

7.1.10. Increased Expression in the Colon Mucosa with Inflammatory Bowel Disease. IL-8 is produced in the colonic lamina propria of patients with inflammatory bowel disease.

There is no difference in IL-8 protein concentrations between inflamed mucosa of patients with Crohn's disease or ulcerative colitis. IL- 8 does thus not permit the differentiation between these two diseases entities. Mucosal IL-8 protein and IL- 8 mRNA concentrations are correlated with the degree of inflammation. IL- 8 mRNA is strongly expressed by intestinal inflammatory cells but not by intestinal epithelial cells suggesting that virtually all IL- 8 is produced by interstitial inflammatory cells [96].

An imbalance of the intestinal immune system with a shift towards proinflammatory mediators is a characteristic feature of inflammatory bowel diseases [97]. Among the 
proinflammatory cytokines, IL-8 together with IL-1 and tumour necrosis factor play an important part.

IL-8 is synthesised by various colonic cancer cell lines like HT-29 cells or Caco-2 cells [98]. Evidence has also been provided that isolated normal intestinal epithelial cells may synthesise IL-8 [98].

An increased synthesis of IL-8 has been described in the mucosa of patients with inflammatory bowel disease. Where Mahida and coworkers [99] found enhanced mucosal tissue concentrations of IL-8 essentially only in patients with ulcerative colitis but not in patients with Crohn's disease, Izzo et al. [100] detected increased concentrations of IL-8 also in the colonic mucosa from patients with Crohn's disease.

7.1.11. Promotion of Endometriosis Pathogenesis. IL-8 is representative of $\alpha$-chemokine group and is a chemotactic and angiogenic factor [101]. It acts as an endometrial autocrine and paracrine factor and regulates many physiologic processes such as menstruation and remodeling of endometrium [102]. In addition, IL-8 also contributes to the pathogenesis of endometriosis by promoting a vicious cycle of endometrial cell attachment, invasion, immune protection, cell growth, and further secretion [103].

The presence of inflammation and neovascularization observed in and around ectopic endometrial implants and the presence of inflammatory neutrophils in these lesions [104] is compatible with the biological actions of IL-8 [105]. IL-8 is detectable in the peritoneal fluid of most women with an active ovarian cycle, and it is a normal constituent of peritoneal fluid in women with and without endometriosis. The concentration of IL-8 in the peritoneal fluid was higher in women with endometriosis compared to women without, and that difference was statistically significant as has been reported previously $[106,107]$.

Peripheral blood macrophages from endometriosis patients produced increased concentrations of IL-8 [101]. In women with early endometriosis (American Fertility Society Stage 1), IL-8 concentrations is much high as compared to women with later stages of the disease. It can be speculated that this may implicate IL-8 in the induction of the disease, and it is conceivable that other chemokines participate in the chronic phase of endometriosis. There are a number of potential cellular sources of IL-8 in endometriosis. Enhanced production by peritoneal macrophages has been found [107], but normal endometrial gland cells [108] and stromal cells [109] also produce IL-8 that can be enhanced by proinflammatory mediators. In normal nonpregnant endometrium, IL-8 was found to be localized perivascularly [102], suggestive of a direct role upon endothelial cells as well as a function in presenting a fixed chemotactic stimulus to circulating leukocytes.

7.1.12. Intervertebral Disc Causing Low Back Pain. Human NP (nucleus pulposus) produces IL-8. Significant quantities of IL-6, IL-8, and PGE2 were produced by both the sciatica and low back pain groups.

Burke et al. studied the production of inflammatory mediators in disc tissues in a similar group of patients
[110] and compared the levels of IL-6, IL-8, and PGE2 in their disc tissue from patients undergoing discectomy for sciatica with those from patients undergoing fusion for discogenic low back pain which showed that more IL-6, IL8 , and PGE2 are produced by discs from patients with low back pain compared with discs from patients with sciatica. There was a trend towards less exposure of the NP in the group with low back pain only compared with those with sciatica introducing a bias towards higher levels of mediator production in the latter [111].

The rates of production of IL- 6 and IL- 8 in the AI and EXT categories of discs in low back pain are much higher than those found in those with sciatica. A combination of the innervation of the NP and increased production of proinflammatory mediators suggests that the mechanism for discogenic low back pain may be the induction of hyperalgesia in the newly innervated degenerating NP. Both IL-8 and PGE2 are known to induce hyperalgesia [112].

7.2. IL-8 and Cancer. The extensive effects of increased IL-8 activity on tumor pathogenesis make it a unique therapeutic target in cancer therapy. For example, IL-8 promotes tumor growth, angiogenesis, and metastasis in murine models of several cancers [113]. Moreover, blocking IL-8 activity with a monoclonal antibody has been shown to decrease tumor growth in two murine cancer models [114]. Blockade of IL-8 expression in some human melanoma cell lines by antisense RNA has shown that IL-8 functions as an autocrine growth modulator for these cells [33].

7.2.1. High Expression in Ovarian Cancer. IL-8 is expressed at high levels in ovarian cancer cells where expression is correlated with tumorigenicity [115]. IL-8 is overexpressed in most human cancers, including ovarian carcinoma [116]. Induction of IL- 8 expression is mediated primarily by the transcription factor NF- $\kappa \mathrm{B}$ [117]; however, the Src/signal transducer and activator of transcription 3 (Stat3) pathways may also promote IL- 8 production independent of NF- $\kappa \mathrm{B}$ [118]. High tumor IL-8 expression is significant in ovarian cancer associated with advanced tumor stage and high-tumor grade. The higher the IL-8, the poorer the survival rate. IL-8 overexpression in ovarian cancer is associated with decreased patient survival and is an independent prognostic factor for poor clinical outcome that targeted therapy with IL-8 siRNA-DOPC in combination with chemotherapy effectively reduced tumor growth in both chemotherapy-sensitive and chemotherapy-resistant ovarian cancer models [119]. these antitumor effects are likely due to a reduction in proangiogenic factors present in the tumor microenvironment that led to decreased angiogenesis and tumor cell proliferation following silencing IL-8 expression. IL- 8 may be a potential therapeutic target in ovarian cancer. IL-8 overexpression is reported in multiple malignancies and is frequently associated with poor clinical outcome [120].

Several studies have examined the utility of IL- 8 as a diagnostic or prognostic marker in patients with ovarian cancer [121-123]. For example, increased IL-8 expression in ovarian cyst fluid, ascites, serum, and tumor tissue from 
ovarian cancer patients is found to be associated with highgrade and advanced-stage cancers, as well as with decreased disease-related patient survival $[121,123]$. Collectively, these data provide the rationale for targeting IL- 8 as a therapeutic approach in ovarian carcinoma.

Decrease in IL-8 expression, especially when combined with taxane-based chemotherapy, led to a statistically significant reduction in orthotopic tumor growth. Xu and Fidler [36] reported that IL-8 overexpression was directly associated with increased tumor vascularity and tumor cell proliferation in ovarian carcinoma.

\subsubsection{Enhancement of Cancer Mechanism in Melanoma.} In melanoma, increased IL-8 levels are associated with increased tumor angiogenesis; conversely, a reduction in tumor microvessel density occurred following treatment with an anti-IL-8 antibody [124]. IL-8 has also been shown to increase tumor cell proliferation and to prolong the survival of human endothelial cells and enhance their ability to form tubules, which supports the theory that the proangiogenic effects of IL- 8 are due to activation of both tumor and endothelial cells $[113,124]$.

Members of the MMP family of proteins promote tumor angiogenesis as well as cellular detachment, invasion, and metastasis, and some MMP family members, including MMP-2 and MMP-9, are reported to be regulated by IL8 expression $[125,126]$. IL- 8 induces MMP-2 and MMP9 expression in bladder cancer and melanoma cell lines, which contributed to increased tumor cell invasion in vitro $[113,126]$.

7.2.3. Increase of VEGF and Neuropilin Expression in Pancreatic Cancer. IL-8 is upregulated in both cancer and chronic inflammatory diseases of the pancreas [127]. It is linked to pancreatic cancer tumorigenesis primarily through its regulation of angiogenesis and metastasis [120]. Human umbilical vein endothelial cells (HUVECs) proliferation and angiogenesis are both increased when cocultured with pancreatic cancer cells, or with exogenous in IL-8. The increase of cell proliferation and angiogenesis of HUVEC can be blocked by IL-8-neutralizing antibodies [128].

IL- 8 is associated with chronic diseases of the pancreas [127]. It is overexpressed in most human pancreatic cancer tissues [120]. Higher IL-8 levels in pancreatic cancer patient serum are associated with significant weight loss [129]. The expression levels of IL-8 appear to correlate with their tumorigenic and metastatic potential in an orthotopic xenograft model [130]. Furthermore, treatment with exogenous IL- 8 increases the invasiveness of human pancreatic cancer cell, while blocking IL- 8 inhibited the growth of another human pancreatic cancer cell [131]. Blocking IL-8 in pancreatic cancer cells decreased their growth and their ability to attach to endothelial cells, suggesting that IL-8 is an autocrine mitogenic factor important for metastasis [132].

The expression of IL-8 can be induced by many stimuli including lipopolysaccharide, phorbol 12-myristate 13acetate (PMA), IL-1, and TNF. Several stress factors, such as hypoxia, acidosis, nitric oxide (NO), and cell density, also significantly influenced the production of IL- 8 in human pancreatic cancer cells [133].

IL-8 is involved in cancer hypoxia pathway where its expression is regulated by hypoxia-inducible factor-1 (HIF-1), NF- $\kappa \mathrm{B}$, and KRAS [128]. IL-8 overexpressed in pancreatic cancer increases MMP-2 activity and plays an important role in the invasiveness of human pancreatic cancer [130, $131,134]$, and human pancreatic cancer is associated with increased expression of IL-8 [127].

IL-8 as a proantigenic cytokine that helps the spread of distant metastasis by neovascularization and promotes the survival of the tumor mass in general by maintaining a rich capillary network to accommodate the heavy nutrient requirements of this aggressive cancer. Blocking IL- 8 and IL-8 receptor CXCR2 significantly inhibited angiogenesis $[118,135]$.

Both IL-8 and VEGF are important components in cellular response to hypoxia, a common event in cancer, including human melanoma, colon cancer, and pancreatic cancer [117]. IL-8 acts as a direct growth and survival factor on pancreatic cancer cells, and IL-8 as multifaceted regulator of gene expression can regulate multiple pathways including angiogenesis, metastasis, and response to hypoxia in pancreatic cancer [136].

\subsubsection{Expression in the Neuroendocrine and Nonneuroen-} docrine Compartments of Prostate Cancer. Moore et al. demonstrated that IL-8 is a positive regulator of tumor formation in severe combined immunodeficiency (SCID) in mice injected with the prostate cancer cell line PC-3 [137]. Patients with PC (prostate cancer) have high serum levels of IL- 8 which correlates with the stage of the disease. Additionally, in PC serum IL-8 levels have been determined to be an independent prognostic variable from the serum levels of free and total prostate-specific antigen (PSA) [138]. The combined use of free and total PSA ratio and IL- 8 levels has been found to be more accurate in distinguishing between prostate cancer and benign prostatic hypertrophy.

In PC, serum IL-8 levels increase with progression of the disease [139]. The PC cell line 3 expresses and secretes IL-8 [140] and expresses IL-8 receptors CXCR1 and CXCR2 [140]. IL-8 is a mitogenic [21] and angiogenic factor [141]. PC cell line LNCaP does not express IL-8, but selection of the cells in androgen-deprived media led to the emergence of a cell line that produces IL- 8 and is more tumorigenic than the parental cells [141].

The IL- 8 receptor CXCR1 is rarely expressed in benign epithelial cells, its expression is increased in PIN (pancreatic invasive neoplasm), and further increase in invasive tumor suggests paracrine mechanism where IL- 8 produced by the NE tumor cells may promote the proliferation of the nonNE tumor cells in the absence of androgen [142].

7.2.5. Metastatic Factor in Breast Cancer. Estrogen receptor (ER) status is an important parameter in breast cancer management as ER-positive breast cancers have a better prognosis than ER-negative tumors. IL- 8 is overexpressed in most ER-negative breast, ovary cell lines, and breast cancer, 
whereas no significant IL-8 levels are found in ER-positive breast or ovarian cell lines. IL- 8 is considered as a potential metastatic factor in breast cancers [38]. IL- 8 is found not only in normal but also in cancerous breast [37, 143].

Metastasis represents the major remaining cause of mortality in human breast cancer, which suggests that invasiveness is associated with lack of ER and changes in IL-8 expression. However, there was no correlation between ER $\beta$ expression and IL- 8 level, indicating $\mathrm{ER} \alpha$, the main estrogen receptor in ER-positive breast and ovarian cancer cells, is the receptor linked to IL-8 expression. Patients with recurrent prostate, breast, or ovarian cancer exhibit higher levels of IL8 in serum or peripheral blood leukocytes [138, 144, 145] and in cancer tissues [34]. Several studies show that IL-8 expression in breast tumors is identical between normal and cancer tissue $[146,147]$.

Concerning IL-8 receptors, CXCR1 expression is extremely low in all lines, whereas most of the cells show a nice expression of CXCR2, without any correlation with ER status [143]. CXCR1 and CXCR2 which are encoded by two distinct genes [148, 149] are expressed in most cancer cells with no apparent correlation with the grade of the tumor [150, 151].

Exogenous expression of IL-8 increases by twofold the invasion rate of ER-positive breast cancer cells, without affecting the in vitro proliferation rate of these cells which is the proinvasive role of IL-8. When IL-8 is transfected in cancer cells, both tumor inhibition [152, 153] and promotion $[126,154]$ have been observed in vivo depending on the cell type [155].

7.2.6. BEV (Epstein Barr Virus) and NPC (Nasopharyngeal Tumor). Several chemokines secreted from EBV-infected NPC cells are increased upon EBV reactivation into the lytic cycle, and IL-8 is upregulated most significantly [156].

The most frequent histological type of NPC is closely associated with Epstein-Barr virus (EBV) infection [157]. NPC exhibits several inflammatory features in the tumor tissues, including intensive leukocyte infiltration, abundant expression of inflammatory cytokines, and constitutive activation of inflammation-associated transcription factors [158]. Expression of several chemokines has been demonstrated in NPC tumors, including IL-8, macrophage inflammatory proteins (MIPs), macrophage chemoattractant proteins (MCPs), and RANTES [159].

EBV reactivation in NPC cells is associated with the induction of certain chemokines where IL-8 was upregulated most significantly and consistently [147].

Neutrophils first invoke into inflamed tissues, then they produce a variety of chemokines with potentials to direct sequential recruitment of other leukocytes [160]. Therefore, by initial recruitment of neutrophils, IL- 8 may trigger the subsequent influx of leukocytes in NPC. Notably, neutrophil infiltration promoted by tumor-derived IL- 8 has been linked to the poor prognosis of bronchioloalveolar carcinoma and to increased genetic instability of Mutatect tumors [161], suggesting that IL-8-attracted neutrophils may contribute to tumorigenesis.
IL-8 is associated with the level of vascularization in NPC $[159,162]$. Moreover, NPC is a highly metastatic cancer, and IL- 8 may be involved in the phenotype since it can promote tumor invasion or metastasis through induction of certain metalloproteinases [154].

IL-8 is a converged target gene of gammaherpesviruses in both latent and lytic infection states. EBV utilizes the lytic protein Zta and the latent protein LMP1 to induce IL8 expression, while Kaposi's sarcoma-associated herpesvirus (KSHV) can upregulate IL-8 by either the lytic protein K15 or the latent protein K13 [163]. Since KSHV-associated Kaposi's sarcoma also exhibits several inflammation-like features, induction of IL- 8 is likely to be critical for the virus-mediated "inflammatory tumorigenesis"; [159, 162].

Blockage of IL- 8 or IL- 8 receptors may be considered a potential therapeutic approach for treating NPC or other inflammation-related malignancies [156].

\section{Conclusion}

IL-8, a potent angiogenic, proinflammatory, growth-promoting factor, properties which may be shared by other chemokines [164], is also a chemoattractant for neutrophils and induces expression of several cell adhesion molecules [164]. It also lead to neutrophil activation [165] and hence might contribute to the pathogenesis of inflammatory diseases. IL-8 specifically chemoattracts several cell types, which is the basis for inflammation. Neovascularization is a crucial step in tumor growth and metastasis. Regulation of IL 8 production is a key mediator of inflammation by NF- $\kappa \mathrm{B}$. The receptors for IL-8 are widely expressed on normal and various tumor cells.

IL-8 induces proinflammatory, chemotactic, and matrix, degradative responses in many pathologies. More research will certainly help to achieve a much better understanding of the function of IL- 8 in different pathologies. However, knowledge gained from IL-8 data might be applied in a foreseeable future to cure the low back pain that often accompanies disc degeneration and therefore be beneficial for the patient. Despite exciting advances on IL-8, significant technical obstacles still have to be overcome before such approaches become realistic alternative therapeutic options to conventional surgical intervention procedures. Studies to understand IL- 8 gene expression in the various cell types may lead to new therapeutics to enhance or inhibit IL-8 production. Many outstanding questions regarding IL-8 and inflammation exist. Further examination pin pointing the role of different IL-8 expressing subsets will allow us to better understand this cytokine.

\section{Abbreviations}

IL: Interleukin

ROS: Reactive oxygen species

TNF- $\alpha$ : Tumor necrosis factor- $\alpha$

TGF: Tumor growth factor

INF: Interferons

NGF: Nerve growth factor

BAL: Bronchoalveolar lavage 
NF- $\kappa$ B: $\quad$ Nuclear factor $-\kappa B$

MMP: Matrix metalloproteinases

VEGFR: Vascular endothelial growth factor receptor

GRO: Melanoma growth stimulatory activity

MIP: $\quad$ Macrophage inflammatory protein

NAP: Neutrophil-activating protein

CTAP: $\quad$ Connective tissue-activating protein

BK: $\quad$ Bradykinin

NGF: $\quad$ Nerve growth factor

BAL: Bronchoalveolar lavage

CF: $\quad$ Cystic fibrosis

PGE: Prostaglandin

AP: $\quad$ Activator protein

RSV: $\quad$ Respiratory syncytial virus

NP: $\quad$ Nucleus pulposus

HUVECs: Human umbilical vein endothelial cells

NO: $\quad$ Nitric oxide

HIF: Hypoxia-inducible factor

ER: $\quad$ Estrogen receptor

BEV: $\quad$ Epstein Barr virus

NPC: $\quad$ Nasopharyngeal tumor

MIP: $\quad$ Macrophage inflammatory proteins

MCP: Macrophage chemoattractant proteins

KSHV: Kaposi's sarcoma-associated herpesvirus.

\section{References}

[1] K. Matsushima and J. J. Oppenheim, "Interleukin 8 and MCAF: novel inflammatory cytokines inducible by IL 1 and TNF," Cytokine, vol. 1, no. 1, pp. 2-13, 1989.

[2] I. Dobreva, G. Waeber, R. W. James, and C. Widmann, "Interleukin- 8 secretion by fibroblasts induced by low density lipoproteins is p38 MAPK-dependent and leads to cell spreading and wound closure," Journal of Biological Chemistry, vol. 281, no. 1, pp. 199-205, 2006.

[3] J. M. Schröder, "The neutrophil-activating peptide 1/interleukin 8, a novel neutrophil chemotactic cytokine," Archivum Immunologiae et Therapia Experimentalis, vol. 40, pp. 23-31, 1992.

[4] J. E. Feugate, Q. Li, L. Wong, and M. Martins-Green, "The cxc chemokine cCAF stimulates differentiation of fibroblasts into myofibroblasts and accelerates wound closure," Journal of Cell Biology, vol. 156, no. 1, pp. 161-172, 2002.

[5] N. Mukaida, A. Hishinuma, C. O. C. Zachariae, J. J. Oppenheim, and K. Matsushima, "Regulation of human interleukin 8 gene expression and binding of several other members of the intercrine family to receptors for interleukin8," Advances in Experimental Medicine and Biology, vol. 305, pp. 31-38, 1991.

[6] M. Lotz, R. Terkeltaub, and P. M. Villiger, "Cartilage and joint inflammation: regulation of IL-8 expression by human articular chondrocytes," Journal of Immunology, vol. 148, no. 2, pp. 466-473, 1992.

[7] M. Baggiolini and I. Clark-Lewis, "Interleukin-8, a chemotactic and inflammatory cytokine," FEBS Letters, vol. 307, no. 1, pp. 97-101, 1992.

[8] J. J. Oppenheim, K. Matsushima, C. G. Larsen, and A. O. Anderson, "Production of interleukin- 8 by human dermal fibroblasts and keratinocytes in response to interleukin-1 or tumour necrosis factor," Immunology, vol. 68, no. 1, pp. 3136, 1989.

[9] Y. Terui, M. Ikeda, H. Tomizuka et al., "Activated endothelial cells induce apoptosis in leukemic cells by endothelial interleukin-8," Blood, vol. 92, no. 8, pp. 2672-2680, 1998.

[10] R. Brew, J. S. Erkson, D. C. West, B. F. Flanagan, and S. E. Christmas, "Interleukin-8 as a growth factor for human colorectal carcinoma cells in vitro," Biochemical Society Transactions, vol. 25, no. 2, p. 264S, 1997.

[11] J. M. Farber, "A macrophage mRNA selectively induced by $\gamma$ interferon encodes a member of the platelet factor 4 family of cytokines," Proceedings of the National Academy of Sciences of the United States of America, vol. 87, no. 14, pp. 5238-5242, 1990.

[12] H. Zhang, G. H. Thorgaard, and S. S. Ristow, "Molecular cloning and genomic structure of an interleukin-8 receptor-like gene from homozygous clones of rainbow trout (Oncorhynchus mykiss)," Fish and Shellish Immunology, vol. 13, no. 3, pp. 251-258, 2002.

[13] M. Z. Norzila, K. Fakes, R. L. Henry, J. Simpson, and P. G. Gibson, "Interleukin-8 secretion and neutrophil recruitment accompanies induced sputum eosinophil activation in children with acute asthma," American Journal of Respiratory and Critical Care Medicine, vol. 161, no. 3, part 1, pp. 769-774, 2000.

[14] M. L. Barnett, K. A. Lamb, K. M. Costello, and M. C. Pike, "Characterization of interleukin-8 receptors in human neutrophil membranes: regulation by guanine nucleotides," Biochimica et Biophysica Acta, vol. 1177, no. 3, pp. 275-282, 1993.

[15] C. Schumacher, I. Clark-Lewis, M. Baggiolini, and B. Moser, "High- and low-affinity binding of GRO $\alpha$ and neutrophilactivating peptide 2 to interleukin 8 receptors on human neutrophils," Proceedings of the National Academy of Sciences of the United States of America, vol. 89, no. 21, pp. 1054210546, 1992.

[16] D. H. Hechtman, M. I. Cybulsky, H. J. Fuchs, J. B. Baker, and M. A. Gimbrone, "Intravascular IL-8: inhibitor of polymorphonuclear leukocyte accumulation at sites of acute inflammation," Journal of Immunology, vol. 147, no. 3, pp. 883-892, 1991.

[17] M. Krieger, T. Brunner, S. C. Bischoff et al., "Activation of human basophils through the IL-8 receptor," Journal of Immunology, vol. 149, no. 8, pp. 2662-2667, 1992.

[18] F. Q. Cunha, B. B. Lorenzetti, S. Poole, and S. H. Ferreira, "Interleukin-8 as a mediator of sympathetic pain," British Journal of Pharmacology, vol. 104, no. 3, pp. 765-767, 1991.

[19] K. J. van Zee, E. Fischer, A. S. Hawes et al., "Effects of intravenous IL-8 administration in nonhuman primates," Journal of Immunology, vol. 148, no. 6, pp. 1746-1752, 1992.

[20] S. Nourshargh, J. A. Perkins, H. J. Showell, K. Matsushima, T. J. Williams, and P. D. Collins, "A comparative study of the neutrophil stimulatory activity in vitro and proinflammatory properties in vivo of 72 amino acid and 77 amino acid IL-8," Journal of Immunology, vol. 148, no. 1, pp. 106-111, 1992.

[21] A. E. Koch, P. J. Polverini, S. L. Kunkel et al., "Interleukin-8 as a macrophage-derived mediator of angiogenesis," Science, vol. 258, no. 5089, pp. 1798-1801, 1992.

[22] W. S. Simonet, T. M. Hughes, H. Q. Nguyen, L. D. Trebasky, D. M. Danilenko, and E. S. Medlock, "Longterm impaired neutrophil migration in mice overexpressing human interleukin-8," Journal of Clinical Investigation, vol. 94, no. 3, pp. 1310-1319, 1994. 
[23] H. Nakamura, K. Yoshimura, N. G. McElvaney, and R. G. Crystal, "Neutrophil elastase in respiratory epithelial lining fluid of individuals with cystic fibrosis induces interleukin8 gene expression in a human bronchial epithelial cell line," Journal of Clinical Investigation, vol. 89, no. 5, pp. 1478-1484, 1992.

[24] S. C. Donnelly, R. M. Strieter, S. L. Kunkel et al., "Interleukin8 and development of adult respiratory distress syndrome in at-risk patient groups," Lancet, vol. 341, no. 8846, pp. 643647, 1993.

[25] M. Marini, E. Vittori, J. Hollemborg, and S. Mattoli, "Expression of the potent inflammatory cytokines, granulocytemacrophage-colony-stimulating factor and interleukin-6 and interleukin-8, in bronchial epithelial cells of patients with asthma," Journal of Allergy and Clinical Immunology, vol. 89, no. 5, pp. 1001-1009, 1992.

[26] T. J. Standiford, S. L. Kunkel, M. A. Basha et al., "Interleukin8 gene expression by a pulmonary epithelial cell line. A model for cytokine networks in the lung," Journal of Clinical Investigation, vol. 86, no. 6, pp. 1945-1953, 1990.

[27] D. Armstrong, J. B. Jepson, C. A. Keele, and J. W. Stewart, "Pain-producing substance in human inflammatory exudates and plasma," The Journal of physiology, vol. 135, no. 2, pp. 350-370, 1957.

[28] C. A. Dinarello, "Interleukin-1 and its biologically related cytokines," Advances in Immunology, vol. 44, pp. 153-205, 1989.

[29] J. D. Levine and D. B. Reichling, "Peripheral mechanism of inflammatory pain," in Textbook of Pain, pp. 1-59, Churchill livingstone, 4th edition, 1999.

[30] D. E. Hu, Y. Hori, and T. P. D. Fan, "Interleukin-8 stimulates angiogenesis in rats," Inflammation, vol. 17, no. 2, pp. 135143, 1993.

[31] Y. Kitadai, K. Haruma, K. Sumii et al., "Expression of interleukin-8 correlates with vascularity in human gastric carcinomas," American Journal of Pathology, vol. 152, no. 1, pp. 93-100, 1998.

[32] M. W. Lingen, P. J. Polverini, and N. P. Bouck, "Retinoic acid induces cells cultured from oral squamous cell carcinomas to become anti-angiogenic," American Journal of Pathology, vol. 149, no. 1, pp. 247-258, 1996.

[33] D. Schadendorf, A. Moller, B. Algermissen, M. Worm, M. Sticherling, and B. M. Czarnetzki, "IL-8 produced by human malignant melanoma cells in vitro is an essential autocrine growth factor," Journal of Immunology, vol. 151, no. 5, pp. 2667-2675, 1993.

[34] G. F. Greene, Y. Kitadai, C. A. Pettaway, A. C. Von Eschenbach, C. D. Bucana, and I. J. Fidler, "Correlation of metastasis-related gene expression with metastatic potential in human prostate carcinoma cells implanted in nude mice using an in situ messenger RNA hybridization technique," American Journal of Pathology, vol. 150, no. 5, pp. 1571-1582, 1997.

[35] J. J. Lee, G. F. Leedale, and P. Bradbury, An Illustrated Guide to the Protozoa, Society of Protozoologists, Lawrence, Kan, USA, 2nd edition, 2000.

[36] L. Xu and I. J. Fidler, "Interleukin 8: an autocrine growth factor for human ovarian cancer," Oncology Research, vol. 12, no. 2, pp. 97-106, 2000.

[37] F. Basolo, P. G. Conaldi, L. Fiore, S. Calvo, and A. Toniolo, "Normal breast epithelial cells produce interleukin 6 and 8 together with tumor-necrosis factor: defective IL6 expression in mammary carcinoma," International Journal of Cancer, vol. 55, no. 6, pp. 926-930, 1993.
[38] J. E. De Larco, B. R.K. Wuertz, K. A. Rosner et al., "A potential role for interleukin- 8 in the metastatic phenotype of breast carcinoma cells," American Journal of Pathology, vol. 158, no. 2, pp. 639-646, 2001.

[39] A. R. Green, V. L. Green, M. C. White, and V. Speirs, "Expression of cytokine messenger RNA in normal and neoplastic human breast tissue: identification of interleukin-8 as a potential regulatory factor in breast tumours," International Journal of Cancer, vol. 72, no. 6, pp. 937-941, 1997.

[40] S. J. Youngs, S. A. Ali, D. D. Taub, and R. C. Rees, "Chemokines induce migrational responses in human breast carcinoma cell lines," International Journal of Cancer, vol. 71, no. 2, pp. 257-266, 1997.

[41] P. S. Gilmour, I. Rahman, K. Donaldson, and W. MacNee, "Histone acetylation regulates epithelial IL-8 release mediated by oxidative stress from environmental particles," American Journal of Physiology, vol. 284, no. 3, pp. L533L540, 2003.

[42] G. J. Rosenthal, D. R. Germolec, M. E. Blazka et al., "Asbestos stimulates IL-8 production from human lung epithelial cells," Journal of Immunology, vol. 153, no. 7, pp. 3237-3244, 1994.

[43] C. K. Sen, "Cellular thiols and redox-regulated signal transduction," Current Topics in Cellular Regulation, vol. 36, pp. $1-30,2000$

[44] G. Broughton II, J. E. Janis, and C. E. Attinger, "The basic science of wound healing," Plastic and Reconstructive Surgery, vol. 117, supplement 7, pp. 12S-34S, 2006.

[45] N. Vij, A. Sharma, M. Thakkar, S. Sinha, and R. R. Mohan, "PDGF-driven proliferation, migration, and IL8 chemokine secretion in human corneal fibroblasts involve JAK2-STAT3 signaling pathway," Molecular Vision, vol. 14, pp. 1020-1027, 2008.

[46] E. Hoffmann, O. Dittrich-Breiholz, H. Holtmann, and M. Kracht, "Multiple control of interleukin-8 gene expression," Journal of Leukocyte Biology, vol. 72, no. 5, pp. 847-855, 2002.

[47] M. Kracht and J. Saklatvala, "Transcriptional and posttranscriptional control of gene expression in inflammation," Cytokine, vol. 20, no. 3, pp. 91-106, 2002.

[48] J. Chodosh, R. A. Astley, M. G. Butler, and R. C. Kennedy, "Adenovirus keratitis: a role for interleukin-8," Investigative Ophthalmology and Visual Science, vol. 41, no. 3, pp. 783-789, 2000.

[49] J. V. Jester, J. Huang, W. M. Petroll, and H. D. Cavanagh, "TGF $\beta$ induced myofibroblast differentiation of rabbit keratocytes requires synergistic TGF $\beta$, PDGF and integrin signaling," Experimental Eye Research, vol. 75, no. 6, pp. 645$657,2002$.

[50] N. J. Stevenson, S. Haan, A. E. McClurg et al., "The chemoattractants, IL-8 and formyl-methionyl-leucyl-phenylalanine, regulate granulocyte colony-stimulating factor signaling by inducing suppressor of cytokine signaling-1 expression," Journal of Immunology, vol. 173, no. 5, pp. 3243-3249, 2004.

[51] J. E. Oakes, C. A. Monteiro, C. L. Cubitt, and R. N. Lausch, "Induction of interleukin-8 gene expression is associated with herpes simplex virus infection of human corneal keratocytes but not human corneal epithelial cells," Journal of Virology, vol. 67, no. 8, pp. 4777-4784, 1993.

[52] R. Gillitzer, R. Berger, V. Mielke, C. Muller, K. Wolff, and G. Stingl, "Upper keratinocytes of psoriatic skin lesions express high levels of NAP-1/IL-8 mRNA in situ," Journal of Investigative Dermatology, vol. 97, no. 1, pp. 73-79, 1991.

[53] A. E. Koch, S. L. Kunkel, J. C. Burrows et al., "Synovial tissue macrophage as a source of the chemotactic cytokine IL-8," Journal of Immunology, vol. 147, no. 7, pp. 2187-2195, 1991. 
[54] K. J. van Zee, L. E. DeForge, E. Fischer et al., "IL-8 in septic shock, endotoxemia, and after IL-1 administration," Journal of Immunology, vol. 146, no. 10, pp. 3478-3482, 1991.

[55] H. Zwierzina, I. Holzinger, S. Gaggl et al., "Recombinant human interleukin-8 restores function in neutrophils from patients with myelodysplastic syndromes without stimulating myeloid progenitor cells," Scandinavian Journal of Immunology, vol. 37, no. 3, pp. 322-328, 1993.

[56] S. Z. Ding, Y. Minohara, J. F. Xue et al., "Helicobacter pylori infection induces oxidative stress and programmed cell death in human gastric epithelial cells," Infection and Immunity, vol. 75, no. 8, pp. 4030-4039, 2007.

[57] S. E. Crowe, "Helicobacter infection, chronic inflammation, and the development of malignancy," Current Opinion in Gastroenterology, vol. 21, no. 1, pp. 32-38, 2005.

[58] P. B. Ernst, D. A. Peura, and S. E. Crowe, "The translation of Helicobacter pylori basic research to patient care," Gastroenterology, vol. 130, no. 1, pp. 188-206, 2006.

[59] S. E. Crowe, L. Alvarez, M. Dytoc et al., "Expression of interleukin 8 and CD54 by human gastric epithelium after Helicobacter pylori infection in vitro," Gastroenterology, vol. 108, no. 1, pp. 65-74, 1995.

[60] J. E. Crabtree, J. I. Wyatt, L. K. Trejdosiewicz et al., "Interleukin-8 expression in Helicobacter pylori infected, normal, and neoplastic gastroduodenal mucosa," Journal of Clinical Pathology, vol. 47, no. 1, pp. 61-66, 1994.

[61] J. E. Crabtree, T. M. Shallcross, R. V. Heatley, and J. I. Wyatt, "Mucosal tumour necrosis factor $\alpha$ and interleukin6 in patients with Helicobacter pyloris associated gastritis," Gut, vol. 32, no. 12, pp. 1473-1477, 1991.

[62] S. F. Moss and M. J. Blaser, "Mechanisms of disease: inflammation and the origins of cancer," Nature Clinical Practice Oncology, vol. 2, no. 2, pp. 90-97, 2005.

[63] H. M. Shen and S. Pervaiz, "TNF receptor superfamilyinduced cell death: redox-dependent execution," FASEB Journal, vol. 20, no. 10, pp. 1589-1598, 2006.

[64] G. Chen and D. V. Goeddel, "TNF-R1 signaling: a beautiful pathway,” Science, vol. 296, no. 5573, pp. 1634-1635, 2002.

[65] T. Shimada, N. Watanabe, H. Hiraishi, and A. Terano, "Redox regulation of interleukin-8 expression in MKN28 cells," Digestive Diseases and Sciences, vol. 44, no. 2, pp. 266-273, 1999.

[66] F. Yan, S. K. John, G. Wilson, D. S. Jones, M. K. Washington, and D. B. Polk, "Kinase suppressor of Ras-1 protects intestinal epithelium from cytokine-mediated apoptosis during inflammation," Journal of Clinical Investigation, vol. 114, no. 9, pp. 1272-1280, 2004.

[67] S. Chollet-Martin, B. Jourdain, C. Gibert, C. Elbim, J. Chastre, and M. A. Gougerot-Pocidalo, "Interactions between neutrophils and cytokines in blood and alveolar spaces during ARDS," American Journal of Respiratory and Critical Care Medicine, vol. 154, no. 3, part 1, pp. 594-601, 1996.

[68] K. P. Steinberg, J. A. Milberg, T. R. Martin, R. J. Maunder, B. A. Cockrill, and L. D. Hudson, "Evolution of bronchoalveolar cell populations in the adult respiratory distress syndrome," American Journal of Respiratory and Critical Care Medicine, vol. 150, no. 1, pp. 113-122, 1994.

[69] R. B. Goodman, R. M. Strieter, D. P. Martin et al., "Inflammatory cytokines in patients with persistence of the acute respiratory distress syndrome," American Journal of Respiratory and Critical Care Medicine, vol. 154, no. 3, part 1, pp. 602-611, 1996.

[70] J. Pugin, B. Ricou, K. P. Steinberg, P. M. Suter, and T. R. Martin, "Proinflammatory activity in bronchoalveolar lavage fluids from patients with ARDS, a prominent role for interleukin-1," American Journal of Respiratory and Critical Care Medicine, vol. 153, no. 6, part 1, pp. 1850-1856, 1996.

[71] R. P. Baughman, K. L. Gunther, M. C. Rashkin, D. A. Keeton, and E. N. Pattishall, "Changes in the inflammatory response of the lung during acute respiratory distress syndrome: prognostic indicators," American Journal of Respiratory and Critical Care Medicine, vol. 154, no. 1, pp. 76-81, 1996.

[72] N. Sekido, N. Mukaida, A. Harada, I. Nakanishi, Y. Watanabe, and K. Matsushima, "Prevention of lung reperfusion injury in rabbits by a monoclonal antibody against interleukin-8," Nature, vol. 365, no. 6447, pp. 654-657, 1993.

[73] A. P. Metinko, S. L. Kunkel, T. J. Standiford, and R. M. Strieter, "Anoxia-hyperoxia induces monocyte-derived interleukin-8," Journal of Clinical Investigation, vol. 90, no. 3, pp. 791-798, 1992.

[74] L. E. DeForge, A. M. Preston, E. Takeuchi, J. Kenney, L. A. Boxer, and D. G. Remick, "Regulation of interleukin 8 gene expression by oxidant stress," Journal of Biological Chemistry, vol. 268, no. 34, pp. 25568-25576, 1993.

[75] V. Lakshminarayanan, D. W. A. Beno, R. H. Costa, and K. A. Roebuck, "Differential regulation of interleukin-8 and intercellular adhesion molecule- 1 by $\mathrm{H}_{2} \mathrm{O}_{2}$ and tumor necrosis factor- $\alpha$ in endothelial and epithelial cells," Journal of Biological Chemistry, vol. 272, no. 52, pp. 32910-32918, 1997.

[76] R. J. Anto, A. Mukhopadhyay, S. Shishodia, C. G. Gairola, and B. B. Aggarwal, "Cigarette smoke condensate activates nuclear transcription factor- $\kappa \mathrm{B}$ through phosphorylation and degradation of $\mathrm{I} \kappa \mathrm{B} \alpha$ : correlation with induction of cyclooxygenase-2," Carcinogenesis, vol. 23, no. 9, pp. 15111518, 2002.

[77] A. Richter, R. A. O’Donnell, R. M. Powell et al., "Autocrine ligands for the epidermal growth factor receptor mediate interleukin-8 release from bronchial epithelial cells in response to cigarette smoke," American Journal of Respiratory Cell and Molecular Biology, vol. 27, no. 1, pp. 85-90, 2002.

[78] U. Suter, A. A. Welcher, T. Ozcelik et al., "Trembler mouse carries a point mutation in a myelin gene," Nature, vol. 356, no. 6366, pp. 241-244, 1992.

[79] V. C. Broaddus, A. M. Boylan, J. M. Hoeffel et al., "Neutralization of IL-8 inhibits neutrophil influx in a rabbit model of endotoxin-induced pleurisy," Journal of Immunology, vol. 152, no. 6, pp. 2960-2967, 1994.

[80] K. Modelska, J. F. Pittet, H. G. Folkesson, V. Courtney Broaddus, and M. A. Matthay, "Acid-induced lung injury. Protective effect of anti-interleukin-8 pretreatment on alveolar epithelial barrier function in rabbits," American Journal of Respiratory and Critical Care Medicine, vol. 160, no. 5, pp. 1450-1456, 1999.

[81] T. M. Roebuck, S. N. Mattson, and E. P. Riley, "Behavioral and psychosocial profiles of alcohol-exposed children," Alcoholism: Clinical and Experimental Research, vol. 23, no. 6, pp. 1070-1076, 1999.

[82] H. Chandru and V. Boggaram, "The role of sphingosine 1phosphate in the TNF- $\alpha$ induction of IL- 8 gene expression in lung epithelial cells," Gene, vol. 391, no. 1-2, pp. 150-160, 2007.

[83] S. M. Rowe, S. Miller, and E. J. Sorscher, "Cystic fibrosis," New England Journal of Medicine, vol. 352, no. 19, pp. 1992-2001, 2005.

[84] M. M. Zaman, A. Gelrud, O. Junaidi et al., "Interleukin 8 secretion from monocytes of subjects heterozygous for the $\Delta \mathrm{F} 508$ cystic fibrosis transmembrane conductance regulator 
gene mutation is altered," Clinical and Diagnostic Laboratory Immunology, vol. 11, no. 5, pp. 819-824, 2004.

[85] S. Caristi, G. Piraino, M. Cucinotta, A. Valenti, S. Loddo, and D. Teti, "Prostaglandin E2 induces interleukin- 8 gene transcription by activating C/EBP homologous protein in human T lymphocytes," Journal of Biological Chemistry, vol. 280, no. 15, pp. 14433-14442, 2005.

[86] D. S. Armstrong, K. Grimwood, R. Carzino, J. B. Carlin, A. Olinsky, and P. D. Phelan, "Lower respiratory infection and inflammation in infants with newly diagnosed cystic fibrosis," British Medical Journal, vol. 310, no. 6994, pp. 15711572, 1995.

[87] M. W. Konstan, K. A. Hilliard, T. M. Norvell, and M. Berger, "Bronchoalveolar lavage findings in cystic fibrosis patients with stable, clinically mild lung disease suggest ongoing infection and inflammation," American Journal of Respiratory and Critical Care Medicine, vol. 150, no. 2, pp. 448-454, 1994.

[88] E. DiMango, H. J. Zar, R. Bryan, and A. Prince, "Diverse Pseudomonas aeruginosa gene products stimulate respiratory epithelial cells to produce interleukin-8," Journal of Clinical Investigation, vol. 96, no. 5, pp. 2204-2210, 1995.

[89] K. Barnett, D. B. Jacoby, J. A. Nadel, and S. C. Lazarus, "The effects of epithelial cell supernatant on contractions of isolated canine tracheal smooth muscle," American Review of Respiratory Disease, vol. 138, no. 4, pp. 780-783, 1988.

[90] G. D. Leikauf, I. F. Ueki, J. H. Widdicombe, and J. A. Nadel, "Alteration of chloride secretion across canine tracheal epithelium by lipoxygenase products of arachidonic acid," American Journal of Physiology, vol. 250, no. 1, part 2, pp. F47-F53, 1986.

[91] B. Poligone and A. S. Baldwin, "Positive and negative regulation of NF- $\kappa$ B by COX-2. Roles of different prostaglandins," Journal of Biological Chemistry, vol. 276, no. 42, pp. 38658 38664, 2001.

[92] A. Agro, C. Langdon, F. Smith, and C. D. Richards, "Prostaglandin E2 enhances interleukin 8 (IL-8) and IL-6 but inhibits GMCSF production by IL-1 stimulated human synovial fibroblasts in vitro," Journal of Rheumatology, vol. 23, no. 5, pp. 862-868, 1996.

[93] N. Sigurs, P. M. Gustafsson, R. Bjarnason et al., "Severe respiratory syncytial virus bronchiolitis in infancy and asthma and allergy at age 13," American Journal of Respiratory and Critical Care Medicine, vol. 171, no. 2, pp. 137-141, 2005.

[94] Q. Xiu, M. Fujimura, M. Nomura et al., "Bronchial hyperresponsiveness and airway neutrophil accumulation induced by interleukin- 8 and the effect of the thromboxane A2 antagonist S-1452 in guinea-pigs," Clinical and Experimental Allergy, vol. 25, no. 1, pp. 51-59, 1995.

[95] A. Heinzmann, I. Ahlert, T. Kurz, R. Berner, and K. A. Deichmann, "Association study suggests opposite effects of polymorphisms within IL8 on bronchial asthma and respiratory syncytial virus bronchiolitis," Journal of Allergy and Clinical Immunology, vol. 114, no. 3, pp. 671-676, 2004.

[96] K. Mitsuyama, A. Toyonaga, E. Sasaki et al., "IL-8 as an important chemoattractant for neutrophils in ulcerative colitis and Crohn's disease," Clinical and Experimental Immunology, vol. 96, no. 3, pp. 432-436, 1994.

[97] C. P. Braegger, S. Nicholls, S. H. Murch, S. Stephens, and T. T. MacDonald, "Tumour necrosis factor alpha in stool as a marker of intestinal inflammation," Lancet, vol. 339, no. 8785, pp. 89-91, 1992.

[98] L. Eckmann, H. C. Jung, C. Schurer-Maly, A. Panja, E. Morzycka-Wroblewska, and M. F. Kagnoff, "Differential cytokine expression by human intestinal epithelial cell lines: regulated expression of interleukin 8," Gastroenterology, vol. 105, no. 6, pp. 1689-1697, 1993.

[99] Y. R. Mahida, M. Ceska, F. Effenberger, L. Kurlak, I. Lindley, and C. J. Hawkey, "Enhanced synthesis of neutrophilactivating peptide-I/interleukin-8 in active ulcerative colitis," Clinical Science, vol. 82, no. 3, pp. 273-275, 1992.

[100] R. S. Izzo, K. Witkon, A. I. Chen, C. Hadjiyane, M. I. Weinstein, and C. Pellecchia, "Neutrophil-activating peptide (interleukin-8) in colonic mucosa from patients with Crohn's disease," Scandinavian Journal of Gastroenterology, vol. 28, no. 4, pp. 296-300, 1993.

[101] D. P. Braun, H. Gebel, R. House, N. Rana, and W. P. Dmowski, "Spontaneous and induced synthesis of cytokines by peripheral blood monocytes in patients with endometriosis," Fertility and Sterility, vol. 65, no. 6, pp. 1125-1129, 1996.

[102] H. O. D. Critchley, R. W. Kelly, and J. Kooy, "Perivascular location of a chemokine interleukin- 8 in human endometrium: a preliminary report," Human Reproduction, vol. 9, no. 8, pp. 1406-1409, 1994.

[103] M. B. Furie and G. J. Randolph, "Chemokines and tissue injury," American Journal of Pathology, vol. 146, no. 6, pp. 1287-1301, 1995.

[104] O. Khorram, R. N. Taylor, I. P. Ryan, T. J. Schall, and D. V. Landers, "Peritoneal fluid concentrations of the cytokine RANTES correlate with the severity of endometriosis," American Journal of Obstetrics and Gynecology, vol. 169, no. 6, pp. 1545-1549, 1993.

[105] M. Van Deuren, A. S. M. Dofferhoff, and J. W. M. Van der Meer, "Cytokines and the response to infection," Journal of Pathology, vol. 168, no. 4, pp. 349-356, 1992.

[106] I. P. Ryan, J. F. Tseng, E. D. Schriock, O. Khorram, D. V. Landers, and R. N. Taylor, "Interleukin-8 concentrations are elevated in peritoneal fluid of women with endometriosis," Fertility and Sterility, vol. 63, no. 4, pp. 929-932, 1995.

[107] N. Rana, D. P. Braun, R. House, H. Gebel, C. Rotman, and W. P. Dmowski, "Basal and stimulated secretion of cytokines by peritoneal macrophages in women with endometriosis," Fertility and Sterility, vol. 65, no. 5, pp. 925-930, 1996.

[108] S. Saito, T. Kasahara, S. Sakakura, H. Umekage, N. Harada, and M. Ichijo, "Detection and localization of interleukin-8 mRNA and protein in human placenta and decidual tissues," Journal of Reproductive Immunology, vol. 27, no. 3, pp. 161172, 1994.

[109] A. Arici, P. C. MacDonald, and M. L. Casey, "Progestin regulation of interleukin- 8 mRNA levels and protein synthesis in human endometrial stromal cells," Journal of Steroid Biochemistry and Molecular Biology, vol. 58, no. 1, pp. 71-76, 1996.

[110] J. G. Burke, R. W. G. Watson, D. McCormack, F. E. Dowling, M. G. Walsh, and J. M. Fitzpatrick, "Intervertebral discs which cause low back pain secrete high levels of proinflammatory mediators," Journal of Bone and Joint Surgery, Series B, vol. 84, no. 2, pp. 196-201, 2002.

[111] J. D. Kang, M. Stefanovic-Racic, L. A. McIntyre, H. I. Georgescu, and C. H. Evans, "Toward a biochemical understanding of human intervertebral disc degeneration and herniation: contributions of nitric oxide, interleukins, prostaglandin E2, and matrix metalloproteinases," Spine, vol. 22, no. 10, pp. 1065-1073, 1997.

[112] J. M. Cunha, F. Q. Cunha, S. Poole, and S. H. Ferreira, "Cytokine-mediated inflammatory hyperalgesia limited by interleukin-1 receptor antagonist," British Journal of Pharmacology, vol. 130, no. 6, pp. 1418-1424, 2000. 
[113] A. Li, M. L. Varney, J. Valasek, M. Godfrey, B. J. Dave, and R. K. Singh, "Autocrine role of interleukin-8 in induction of endothelial cell proliferation, survival, migration and MMP2 production and angiogenesis," Angiogenesis, vol. 8, no. 1, pp. 63-71, 2005.

[114] B. M. Mian, C. P. N. Dinney, C. E. Bermejo et al., "Fully human anti-interleukin 8 antibody inhibits tumor growth in orthotopic bladder cancer xenografts via down-regulation of matrix metalloproteases and nuclear factor- $\kappa \mathrm{B}$," Clinical Cancer Research, vol. 9, no. 8, pp. 3167-3175, 2003.

[115] J. Yoneda, H. Kuniyasu, M. A. Crispens, J. E. Price, C. D. Bucana, and I. J. Fidler, "Expression of angiogenesis-related genes and progression of human ovarian carcinomas in nude mice," Journal of the National Cancer Institute, vol. 90, no. 6, pp. 447-454, 1998.

[116] A. E. Lokshin, M. Winans, D. Landsittel et al., "Circulating IL-8 and anti-IL-8 autoantibody in patients with ovarian cancer," Gynecologic Oncology, vol. 102, no. 2, pp. 244-251, 2006.

[117] T. Karashima, P. Sweeney, A. Kamat et al., "Nuclear factor$\kappa \mathrm{B}$ mediates angiogenesis and metastasis of human bladder cancer through the regulation of interleukin-8," Clinical Cancer Research, vol. 9, no. 7, pp. 2786-2797, 2003.

[118] J. G. Trevino, M. J. Gray, S. T. Nawrocki et al., "Src activation of Stat3 is an independent requirement from NF$\kappa \mathrm{B}$ activation for constitutive IL-8 expression in human pancreatic adenocarcinoma cells," Angiogenesis, vol. 9, no. 2, pp. 101-110, 2006.

[119] W. M. Merritt, Y. G. Lin, W. A. Spannuth et al., "Effect of interleukin-8 gene silencing with liposome-encapsulated small interfering RNA on ovarian cancer cell growth," Journal of the National Cancer Institute, vol. 100, no. 5, pp. 359-372, 2008.

[120] K. Xie, "Interleukin-8 and human cancer biology," Cytokine and Growth Factor Reviews, vol. 12, no. 4, pp. 375-391, 2001.

[121] S. K. Kassim, E. M. El-Salahy, S. T. Fayed et al., "Vascular endothelial growth factor and interleukin-8 are associated with poor prognosis in epithelial ovarian cancer patients," Clinical Biochemistry, vol. 37, no. 5, pp. 363-369, 2004.

[122] A. Fasciani, G. D’Ambrogio, G. Bocci, S. Luisi, P. G. Artini, and A. R. Genazzani, "Vascular endothelial growth factor and interleukin-8 in ovarian cystic pathology," Fertility and Sterility, vol. 75, no. 6, pp. 1218-1221, 2001.

[123] C. A. Herrera, L. Xu, C. D. Bucana et al., "Expression of metastasis-related genes in human epithelial ovarian tumors," International Journal of Oncology, vol. 20, no. 1, pp. 5-13, 2002.

[124] S. Huang, L. Mills, B. Mian et al., "Fully humanized neutralizing antibodies to interleukin-8 (ABX-IL8) inhibit angiogenesis, tumor growth, and metastasis of human melanoma," American Journal of Pathology, vol. 161, no. 1, pp. 125-134, 2002.

[125] A. Li, S. Dubey, M. L. Varney, B. J. Dave, and R. K. Singh, "IL8 directly enhanced endothelial cell survival, proliferation, and matrix metalloproteinases production and regulated angiogenesis," Journal of Immunology, vol. 170, no. 6, pp. 3369-3376, 2003.

[126] M. Luca, S. Huang, J. E. Gershenwald, R. K. Singh, R. Reich, and M. Bar-Eli, "Expression of interleukin- 8 by human melanoma cells up-regulates MMP-2 activity and increases tumor growth and metastasis," American Journal of Pathology, vol. 151, no. 4, pp. 1105-1113, 1997.
[127] B. Farrow, Y. Sugiyama, A. Chen et al., "Inflammatory mechanisms contributing to pancreatic cancer development," Annals of Surgery, vol. 239, no. 6, pp. 763-771, 2004.

[128] Y. Matsuo, H. Sawai, H. Funahashi et al., "Enhanced angiogenesis due to inflammatory cytokines from pancreatic cancer cell lines and relation to metastatic potential," Pancreas, vol. 28, no. 3, pp. 344-352, 2004.

[129] B. Ebrahimi, S. L. Tucker, D. Li, J. L. Abbruzzese, and R. Kurzrock, "Cytokines in pancreatic carcinoma: correlation with phenotypic characteristics and prognosis," Cancer, vol. 101, no. 12, pp. 2727-2736, 2004.

[130] X. Le, Q. Shi, B. Wang et al., "Molecular regulation of constitutive expression of interleukin-8 in human pancreatic adenocarcinoma," Journal of Interferon and Cytokine Research, vol. 20, no. 11, pp. 935-946, 2000.

[131] Y. Kuwada, T. Sasaki, K. Morinaka, Y. Kitadai, N. Mukaida, and K. Chayama, "Potential involvement of IL-8 and its receptors in the invasiveness of pancreatic cancer cells," International Journal of Oncology, vol. 22, no. 4, pp. 765-771, 2003.

[132] M. Miyamoto, Y. Shimizu, K. Okada, Y. Kashii, K. Higuchi, and A. Watanabe, "Effect of interleukin-8 on production of tumor-associated substances and autocrine growth of human liver and pancreatic cancer cells," Cancer Immunology Immunotherapy, vol. 47, no. 1, pp. 47-57, 1998.

[133] Q. Shi, J. L. Abbruzzese, S. Huang, I. J. Fidler, Q. Xiong, and K. Xie, "Constitutive and inducible interleukin 8 expression by hypoxia and acidosis renders human pancreatic cancer cells more tumorigenic and metastatic," Clinical Cancer Research, vol. 5, no. 11, pp. 3711-3721, 1999.

[134] E. Feijoó, C. Alfaro, G. Mazzolini et al., "Dendritic cells delivered inside human carcinomas are sequestered by interleukin-8," International Journal of Cancer, vol. 116, no. 2, pp. 275-281, 2005.

[135] M. N. Wente, M. P. Keane, M. D. Burdick et al., "Blockade of the chemokine receptor CXCR2 inhibits pancreatic cancer cell-induced angiogenesis," Cancer Letters, vol. 241, no. 2, pp. 221-227, 2006.

[136] M. Li, Y. Zhang, L. W. Feurino et al., "Interleukin-8 increases vascular endothelial growth factor and neuropilin expression and stimulates ERK activation in human pancreatic cancer," Cancer Science, vol. 99, no. 4, pp. 733-737, 2008.

[137] B. B. Moore, D. A. Arenberg, K. Stoy et al., "Distinct CXC chemokines mediate tumorigenicity of prostate cancer cells," American Journal of Pathology, vol. 154, no. 5, pp. 1503-1512, 1999.

[138] R. W. Veltri, M. C. Miller, G. Zhao et al., "Interleukin-8 serum levels in patients with benign prostatic hyperplasia and prostate cancer," Urology, vol. 53, no. 1, pp. 139-147, 1999.

[139] S. Lehrer, E. J. Diamond, B. Mamkine, N. N. Stone, and R. G. Stock, "Serum interleukin-8 is elevated in men with prostate cancer and bone metastases," Technology in Cancer Research and Treatment, vol. 3, no. 5, p. 411, 2004.

[140] J. Reiland, L. T. Furcht, and J. B. McCarthy, "CXCchemokines stimulate invasion and chemotaxis in prostate carcinoma cells through the CXCR2 receptor," Prostate, vol. 41, no. 2, pp. 78-88, 1999.

[141] B. J. Patel, A. J. Pantuck, A. Zisman et al., "Cl1-GFP: an androgen independent metastatic tumor model for prostate cancer," Journal of Urology, vol. 164, no. 4, pp. 1420-1425, 2000.

[142] J. Huang, J. L. Yao, L. Zhang et al., "Differential expression of interleukin- 8 and its receptors in the neuroendocrine 
and non-neuroendocrine compartments of prostate cancer," American Journal of Pathology, vol. 166, no. 6, pp. 1807-1815, 2005.

[143] A. Freund, C. Chauveau, J. P. Brouillet et al., "IL-8 expression and its possible relationship with estrogen-receptor-negative status of breast cancer cells," Oncogene, vol. 22, no. 2, pp. 256265, 2003.

[144] K. Ivarsson, E. Runesson, K. Sundfeldt et al., "The chemotactic cytokine interleukin-8-a cyst fluid marker for malignant epithelial ovarian cancer?" Gynecologic Oncology, vol. 71, no. 3, pp. 420-423, 1998.

[145] A. J. Merogi, A. J. Marrogi, R. Ramesh, W. R. Robinson, C. D. Fermin, and S. M. Freeman, "Tumor-host interaction: analysis of cytokines, growth factors, and tumor-infiltrating lymphocytes in ovarian carcinomas," Human Pathology, vol. 28, no. 3, pp. 321-331, 1997.

[146] V. Speirs, A. R. Green, and M. C. White, "A comparative study of cytokine gene transcripts in normal and malignant breast tissue and primary cell cultures derived from the same tissue samples," International Journal of Cancer, vol. 66, no. 4, pp. 551-556, 1996.

[147] M. W. Madsen and P. Briand, "Relationship between tumorigenicity, in vitro invasiveness, and plasminogen activator production of human breast cell lines," European Journal of Cancer, vol. 26, no. 7, pp. 793-797, 1990.

[148] H. Sprenger, A. R. Lloyd, L. L. Lautens, T. I. Bonner, and D. J. Kelvin, "Structure, genomic organization, and expression of the human interleukin- 8 receptor B gene," Journal of Biological Chemistry, vol. 269, no. 15, pp. 11065-11072, 1994.

[149] H. Sprenger, A. R. Lloyd, R. G. Meyer, J. A. Johnston, and D. J. Kelvin, "Genomic structure, characterization, and identification of the promoter of the human IL-8 receptor A gene," Journal of Immunology, vol. 153, no. 6, pp. 2524-2532, 1994.

[150] L. J. Miller, S. H. Kurtzman, Y. Wang, K. H. Anderson, R. R. Lindquist, and D. L. Kreutzer, "Expression of interleukin8 receptors on tumor cells and vascular endothelial cells in human breast cancer tissue," Anticancer Research, vol. 18, no. 1, pp. 77-81, 1998.

[151] A. Müller, B. Homey, H. Soto et al., "Involvement of chemokine receptors in breast cancer metastasis," Nature, vol. 410, no. 6824, pp. 50-56, 2001.

[152] L.-F. Lee, R. P. Hellendall, Y. Wang et al., "IL-8 reduced tumorigenicity of human ovarian cancer in vivo due to neutrophil infiltration," Journal of Immunology, vol. 164, no. 5, pp. 2769-2775, 2000.

[153] E. Nakashima, A. Oya, Y. Kubota et al., "A candidate for cancer gene therapy: MIP- $1 \alpha$ gene transfer to an adenocarcinoma cell line reduced tumorigenicity and induced protective immunity in immunocompetent mice," Pharmaceutical Research, vol. 13, no. 12, pp. 1896-1901, 1996.

[154] K. Inoue, J. W. Slaton, B. Y. Eve et al., "Interleukin 8 expression regulates tumorigenicity and metastases in androgenindependent prostate cancer," Clinical Cancer Research, vol. 6, no. 5, pp. 2104-2119, 2000.

[155] N. Platet and M. Garcia, "A new bioassay using transient transfection for invasion-related gene analysis," Invasion and Metastasis, vol. 18, no. 4, pp. 198-208, 1998.

[156] M. Hsu, S. Y. Wu, S. S. Chang et al., "Epstein-Barr virus lytic transactivator Zta enhances chemotactic activity through induction of interleukin-8 in nasopharyngeal carcinoma cells," Journal of Virology, vol. 82, no. 7, pp. 3679-3688, 2008.

[157] A. B. Rickinson and E. Kieff, "Epstein-Barr virus," in Fields Virology, D. M. Knipe and P. M. Howley, Eds., pp. 2575-2627,
Lippincott Williams \& Wilkins, Philadelphia, Pa, USA, 4th edition, 2001.

[158] H. Chen, J. M. Lee, Y. Zong et al., "Linkage between STAT regulation and Epstein-Barr virus gene expression in tumors," Journal of Virology, vol. 75, no. 6, pp. 2929-2937, 2001.

[159] M. Buettner, B. Meyer, S. Schreck, and G. Niedobitek, "Expression of RANTES and MCP-1 in epithelial cells is regulated via LMP1 and CD40," International Journal of Cancer, vol. 121, no. 12, pp. 2703-2710, 2007.

[160] P. Scapini, J. A. Lapinet-Vera, S. Gasperini, F. Calzetti, F. Bazzoni, and M. A. Cassatella, "The neutrophil as a cellular source of chemokines," Immunological Reviews, vol. 177, pp. 195-203, 2000.

[161] A. S. Haqqani, J. K. Sandhu, and H. C. Birnboim, "Expression of interleukin-8 promotes neutrophil infiltration and genetic instability in mutatect tumors," Neoplasia, vol. 2, no. 6, pp. 561-568, 2000.

[162] A. Sparmann and D. Bar-Sagi, "Ras-induced interleukin8 expression plays a critical role in tumor growth and angiogenesis," Cancer Cell, vol. 6, no. 5, pp. 447-458, 2004.

[163] Q. Sun, H. Matta, G. Lu, and P. M. Chaudhary, "Induction of IL-8 expression by human herpesvirus 8 encoded vFLIP K13 via NF- $\kappa$ B activation," Oncogene, vol. 25 , no. 19, pp. $2717-$ 2726, 2006.

[164] A. E. Koch, S. L. Kunkel, L. A. Harlow et al., "Enhanced production of monocyte chemoattractant protein-1 in rheumatoid arthritis," Journal of Clinical Investigation, vol. 90, no. 3, pp. 772-779, 1992.

[165] P. Peveri, A. Walz, B. Dewald, and M. Baggiolini, "A novel neutrophil-activating factor produced by human mononuclear phagocytes," Journal of Experimental Medicine, vol. 167, no. 5, pp. 1547-1559, 1988. 


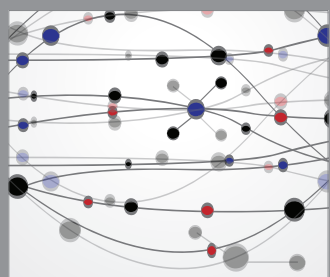

The Scientific World Journal
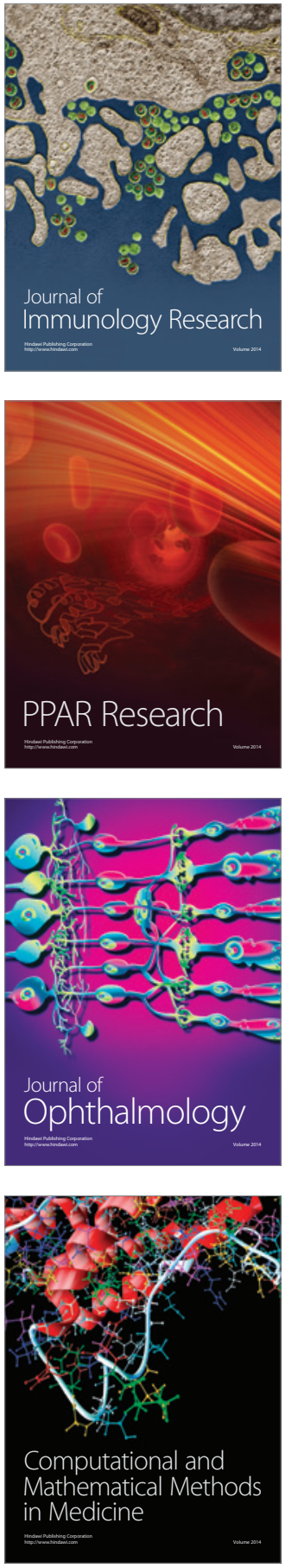

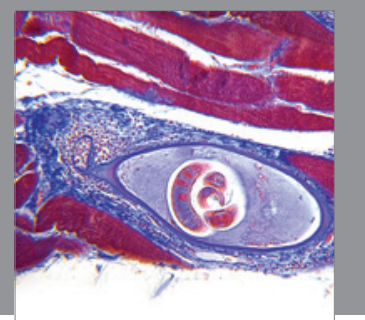

Gastroenterology

Research and Practice
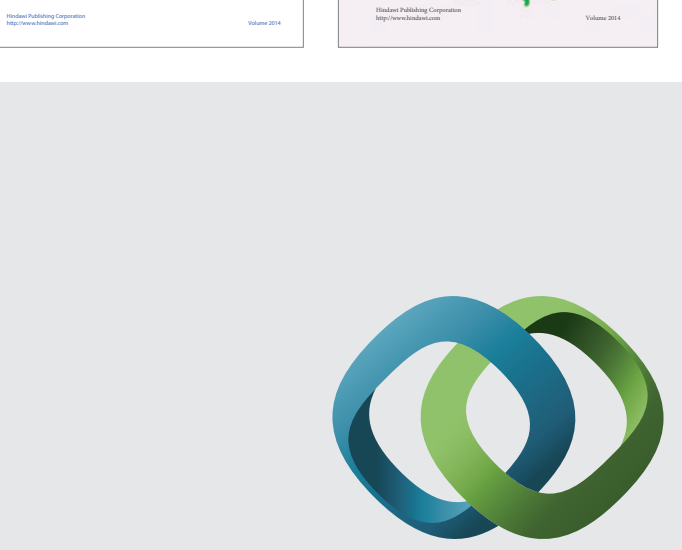

\section{Hindawi}

Submit your manuscripts at

http://www.hindawi.com
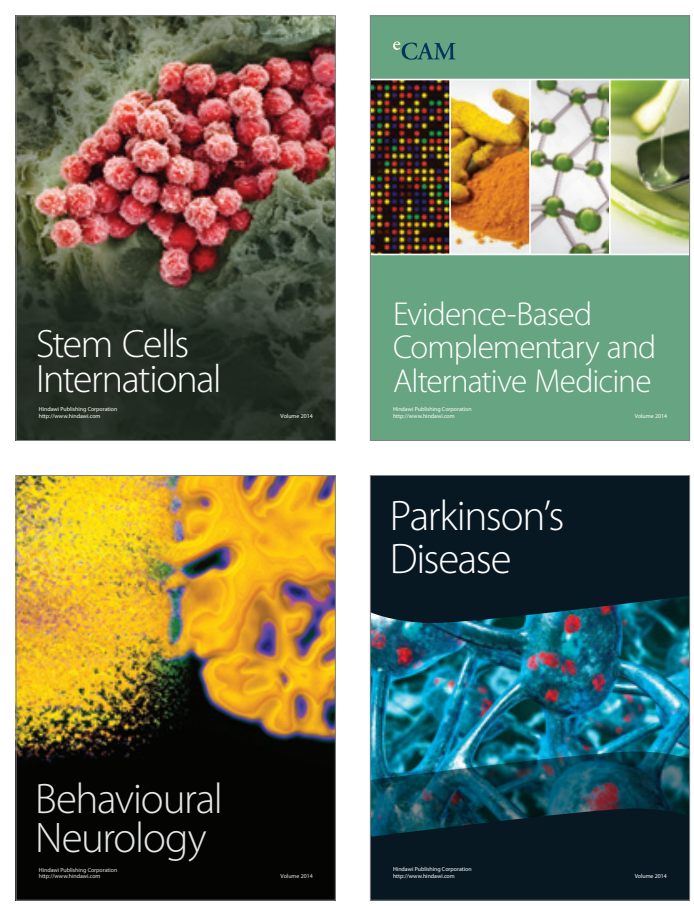

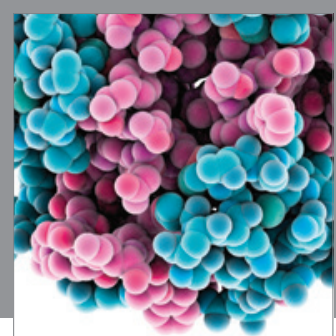

Journal of
Diabetes Research

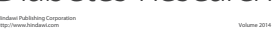

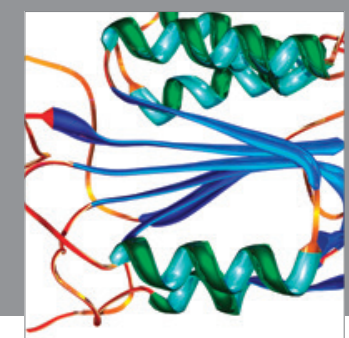

Disease Markers
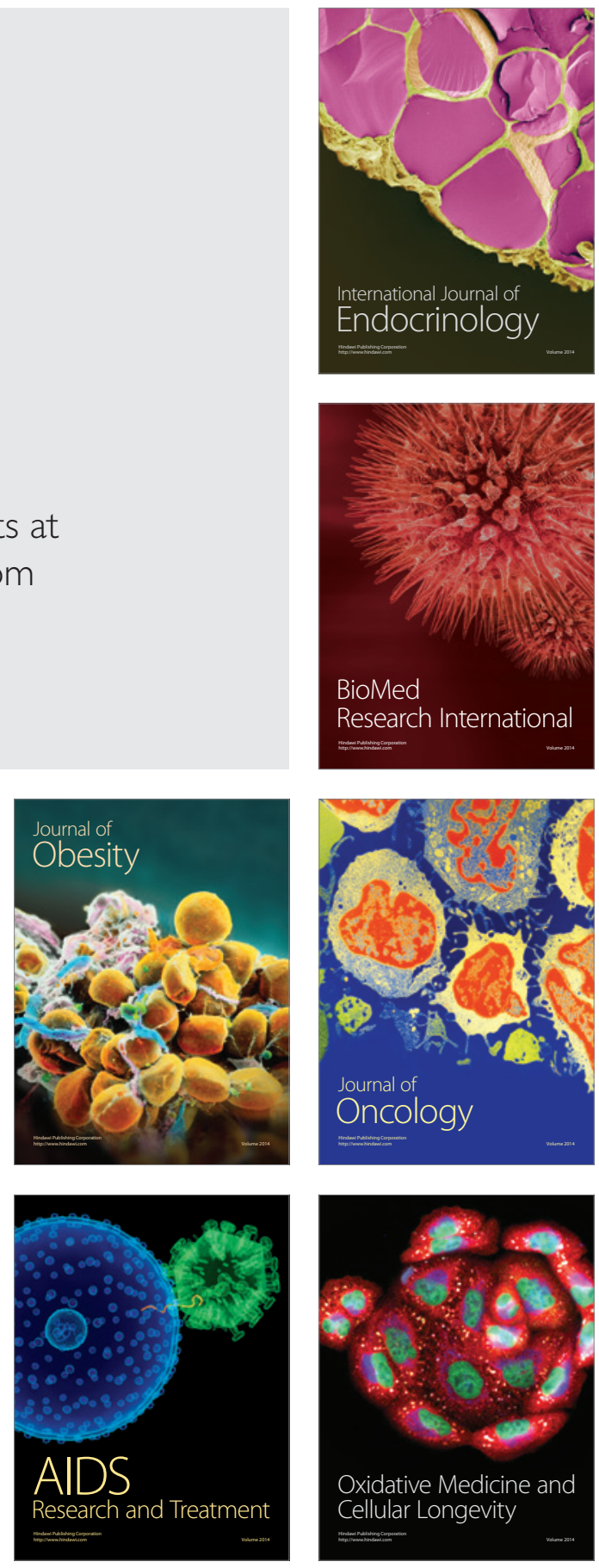